УДК 811.111 '373.7

DOI https://doi.org/10.26661/2414-1135-2021-82-11

\title{
ТЕХНОНІМ У ФРАЗЕОЛОГІЧНІЙ СИСТЕМІ СУЧАСНОЇ АНГЛІЙСЬКОЇ МОВИ
}

\author{
Досанова А. Р. \\ студентка \\ Національний університет «Запорізька політехніка» \\ вул. Жуковського, 64, Запоріжжя, Украӥна \\ orcid.org/0000-0003-2452-5859 \\ dosanova.anastasia@gmail.com \\ Кузнсцова I. В. \\ кандидат філологічних наук, дочент, \\ доиент кафедри теорії та практики перекладу \\ Національний університет «Запорізька політехніка» \\ вул. Жуковського, 64, Запоріжжя, Україна \\ orcid.org/0000-0003-2741-5428 \\ kirina91919@gmail.com
}

Ключові слова: фразеологічна одиниця, антропогенний, натурогенний, план вираження, план змісту, компонент-технонім.
Статтю присвячено виявленню основних теоретичних аспектів існування та функціонування технонімів у фразеології сучасної англійської мови. Проведено аналіз кореляції між лексичним (план вираження) та семантичним (план змісту) підгрунтям фразеологічних одиниць. Також наведена коротка класифікація за лексичним та семантичним підгрунтям фразеологізмів із компонентом-технонімом.

Систематизація фразеологізмів із компонентом-технонімом дає змогу окреслити межі потенційного обсягу зворотів, які формують цей клас онімів. Для констатації факту належності звороту до фразеологізмів i3 компонентом-технонімом варто виходити 3 того, що в його складі потрібно виявити елемент технічної спрямованості. Щоб визначити початкову належність звороту до групи технонімів, варто спиратися на пряме значення того компонента, який має відношення до виробничої діяльності або є результатом виробництва.

Виокремлений технонім характеризують із таких позицій: чи є він пристроєм або механізмом, інструментом або матеріалом, чи відображає будь-яку технічну дію або є іiї результатом. Слід також пам’ятати, що будь-яка фразеологічна одиниця - це єдність двох аспектів: плану змісту й плану вираження.

Лексичне підгрунтя технонімів у складі фразеологізму представлене тим компонентом, який формує технічний образ стійкої конструкції. Воно може бути представлене такими тематичними групами: механізми і споруди, інструменти та матеріали.

Семантичне підгрунтя вбачаємо в тому, що десемантизоване слово-технонім, формуючи образ з іншими компонентами, вирішальним чином бере участь і у формуванні сукупного значення звороту. Тому цей тип систематизації будується з опорою на зареєстроване словниками значення фразеологізму. Таким чином, спираючись на проведене дослідження, можемо стверджувати, що фразеологізми 3 компонентом-технонімом можна класифікувати за лексичним або семантичним підгрунтям, кожне 3 яких має дві тематичні категорії, а саме: механізми і споруди, інструменти та матеріали, вид і застосування матерії, поведінка і стан матерії. 


\title{
TECHNONYMS IN THE PHRASEOLOGICAL SYSTEM OF MODERN ENGLISH LANGUAGE
}

\author{
Dosanova A. R. \\ Student \\ "Zaporizhzhia Polytechnic” National university \\ Zhukovskoho str., 64, Zaporizhzhia, Ukraine \\ orcid.org/0000-0003-2452-5859 \\ dosanova.anastasia@gmail.com \\ Kuznetsova I. V. \\ Candidate of Philological Sciences, Associate Professor, \\ Associate Professor at the Department of Theory and Practice of Translation \\ "Zaporizhzhia Polytechnic" National university \\ Zhukovskoho str., 64, Zaporizhzhia, Ukraine \\ orcid.org/0000-0003-2741-5428 \\ kirina91919@gmail.com
}

Key words: phraseological unit, anthropogenic, naturogenic, expression plan, content plan, technical component.
The article is devoted to the identification of the basic theoretical aspects of the existence and functioning of technonyms in the phraseology of modern English. The correlation between the lexical (expression plan) and semantic (content plan) basis of phraseological units is analyzed. A brief classification by lexical and semantic basis of phraseologisms with the componenttechonym is also given.

The systematization of phraseologisms with technical component makes it possible to outline the limits of the potential volume of units that form a given class of onyms. In order to establish the fact of unit belonging to the phraseologisms with technical component, it should be assumed that in its composition an element of technical orientation is to be identified. To determine belonging of phraseological unit to a group of technonyms, it is necessary to rely on the direct meaning of the component that is relevant to the production activity or is the result of production.

The distinguished technical component is characterized from the following points: whether it is a device or mechanism, tool or material, whether it reflects any technical action or is its result. It should also be remembered that any phraseological unit is a unity of two aspects: a content plan and an expression plan.

The lexical basis of technonyms in phraseologism is represented by the component that forms the technical image of a stable construction. It can be represented by the following thematic groups: mechanisms and structures, tools and materials.

The semantic basis is that the desemanticized technical component forms an image with other components and is decisively involved in the formation of the whole meaning of the unit. Therefore, this type of systematization is built on the basis of the vocabulary meaning of phraseological units.

Thus, based on the study, we can say that phraseologisms with technical component can be classified on a lexical or semantic basis, each of which has two thematic categories, namely: mechanisms and structures, tools and materials, type and use of matter, behavior and the state of matter. 
Словниковий склад будь-якої мови багатий не тільки на базові поняття, але й на образні звороти, так звані фразеологізми або ідіоми. Зазвичай їх використовують, навіть не помічаючи, що, здавалося б, звичайні слова у певному поєднанні мають значення, відмінне від того, яке можна знайти про кожне з них окремо у тлумачному словнику. У цій роботі буде приділена увага технічному аспекту фразеологічного складу мови, а саме фразеологічним одиницям із компонентом-технонімом. Вивчення фразеологічної групи з компонентом-технонімом в англійській та українській мовах тісно пов'язане $з$ дослідженням інших груп фразеологізмів, що загалом сприяє відтворюванню цілісної мовної картини світу. Такий підхід відповідає сучасному розвитку лінгвістичної науки.

Вважаємо, що ця тема не представлена в мовознавстві належним чином, саме цим і зумовлена актуальність роботи.

Об'єктом дослідження виступають англомовні фразеологічні одиниці 3 компонентомтехнонімом.

Предметом дослідження $\epsilon$ аналіз особливостей структури та функціонування фразеологічних одиниць із компонентом-технонімом у сучасній англійській мові та їх переклад українською мовою.

Мета дослідження полягає у визначенні особливостей структури та функціонування фразеологічних одиниць із компонентом-технонімом у сучасній англійській мові.

Дослідження виконане на матеріалі словосполучень, фразеологічних одиниць, відібраних зі словників, сайтів мережі Інтернет, що були присвячені фразеологічним зворотам.

Практичне завдання полягає в можливості застосування його матеріалів у розробленні спецкурсів із фразеології, термінології, проведенні занять із практики перекладу англійської мови, складанні методичних вказівок із теорії та практики перекладу.

Фразеологічні одиниці з технічними компонентами існують в будь-якій мові світу, і це свідчить про те, що техносфера $є$ універсальним поняттям, властивим представникам всього людства, незалежно від культурних, соціальних та економічних відмінностей. Той етнос, який прагне до впровадження різних технологій у своє життя, неминуче збагатить лексичний та фразеологічний пласт своєї мови елементами, які є результатом такої технологізації [2, с. 182]. 3 огляду на це вважаємо, що можна говорити про існування такої групи стійких зворотів, як «фразеологізми з компонентом-технонімом». На нашу думку, до таких фразеологічних одиниць можна зарахувати такі звороти, у складі яких зустрічається компонент, котрий семантично означає об'єкт або процес, що виявляється в технологічному аспекті діяльності людини або є iii результатом. Наприклад, draw water in a sieve (make clothes for fishes) носити воду решетом - робити що-небудь свідомо даремно; play a double gaте - ламати комедію - прикидатися перед кимось; make tracks away from - нагострити лижі - втекти будькуди; burn the candle at both ends (букв.: палити свічку з двох сторін) - марно витрачати ресурси, марнувати життя; play first fiddle (букв.: грати першу скрипку) - займати чільне місие; haтmеr and tongs (букв.: молоток $і$ кусачки) - енергійно, 3 натхненням.

Термін «технонім» можна зустріти в деяких сучасних наукових роботах, наприклад, А.А. Коханської, В.В. Єлькіна та А.В. Ровенської, Т.А. Сироткіної, Л.М. Рильщикової, однак у них це поняття не розкривається в межах фразеологічного фонду мови, а лише згадується як наявне в ономасіології.

Класифікація онімного простору О.В. Суперанської передбачає поділ онімів на групи назв живих істот і істот, які сприймаються як живі, а також неживих істот. До останнього розряду належать техноніми [3, с. 148].

Вважають, що технонім у складі сталого звороту може мати антропогенний або натурогенний характер. Наявність зв'язку техноніма 3 тим типом виробничої матерії, що створила природа, передбачає натурогенність, при цьому людина може докладати певних зусиль, щоб дане природою використовувати для своїх потреб. Це можна побачити на прикладі таких фразеологізмів: rolling stone gathers no тоss - кому на місиі не сидиться, той добра не наживе; constant dripping wears away a stone - крапля камінь точить; run into a stone wall - впертися в кам'яну стіну; зіткнутися з непереборною перешкодою; зайти в глухий кут. Uncle Willie was a rolling stone that gathered no moss. He worked in different jobs all over the country [4]. - Дядьку Віллі на місці не сиділося, тому він не нажив добра, бо працював на різних роботах по всій країні. Dick tried to change Father's mind about letting him use the car Saturday night, but he was up against a stone wall [5]. - Дік намагався змінити думку батька про те, щоб дозволити йому користуватися машиною в суботу ввечері, але зіткнувся з непереборною перешкодою.

Камінь як створений природою технічний інструмент зустрічається в первісному вигляді, $\epsilon$ продуктом природи та, в разі потреби, модифікується людиною. Створені природою об'єкти людина використала для покращення умов свого життя та реалізації науково-технічного прогресу. Тому натурогенні елементи буття, що пізніше стали інструментами для досягнення цілей людства, можна вважати специфічною частиною 
техносфери. Наприклад, green light - зелена вулиия, дозвіл; give the green light - дати зелену вулицю, відкрити илях, надати свободу дій; розв'язати будь-кому руки; let there be light! нехай буде світло! (жартівливий вираз перед вмиканням світла в приміщенні); come to light - вidкриватися; розкритися [1, с. 479]: світло (образ фразеологізму) як люмінесцентне природне явище, яке людина навчилася виробляти самостійно для штучного освітлення. We got the green light to begin a study of the security problems at our school [6]. - Ми отримали дозвіл почати дослідження проблем безпеки в нашій школі.

Антропогенність техноніма, навпаки, пов’язують 3 активними зусиллями людини, спрямованими на виробництво предметів або явищ для отримання конкретної користі або, навпаки, для заподіювання шкоди [2, с. 183]. Отже, ідеться про неживий продукт безпосередньо механістичної діяльності людини. Наприклад, hard as nails - витривалий; sharp as a needle - спостережлива людина; cannon fodder - гарматне м'ясо - недосвідчені новобраниі. У цих зворотах компоненти «цвях, голка, гармата» формують антропогенний характер звороту, адже належать до приладів та механізмів, які використовуються людиною в тих чи інших видах діяльності. Mr. Jameson is one of the best detectives of our police station. He's sharp as a needle and can brilliantly handle difficult cases [5]. - Містер Джеймсон - один iз найкращих детективів нашої поліції. Він спостережлива людина і блискуче може впоратися зі складними справами.

Фразеологізми-техноніми також характеризуються конструктивним та деструктивним початком. Деструктивний вплив частіше за все спричиняє заподіяння шкоди об'єкту, на який цей вплив спрямований [2, с. 183]: raise the roof - влаштувати скандал; kick down the ladder - позбавити nідтримки, допомоги; hit with an iron fist - розправитися залізною рукою (рішуче та жорстоко розв 'язувати питання). Наприклад, в останньому словосполученні англійський варіант містить слово hit, що означає бити, тобто мати переважно деструктивну дію на предмет або людину. It usually happens so that when you need help someone you trust may kick down the ladder and betray you [6]. Зазвичай трапляється так, що, коли вам потрібна допомога, хтось, кому ви довіряєте, може позбавити підтримки і зрадити вас.

Конструктивний вплив - це типова користь, що частіш за все виявляється в результаті певної активності [2, с. 184]. Наприклад, when one's ship comes home - коли кому-небудь пошуастить; thread the needle - закінчити важку роботу; кеер the powder dry - тримати порох сухим (бути в бойовій готовності). В останньому виразі конструктивний вплив виражено за допомогою дієс- лівного компонента keер та прикметникового dry. When my ship comes home we will live in BeverleyHills and eat delicious food every day [5]. - Коли мені пощастить, ми будемо жити на Беверлі-Хіллз і щодня їсти смачну їжу.

Компонент-технонім у складі фразеологізму має межі. Це лексичний та семантичний рівні. Лексичний рівень - набір спеціально підібраних десемантизованих слів, які формують образ. На цьому рівні можна виділити такі типи компонентів-технонімів: механізми та споруди: fight windmills - битися з вітряними млинами, fling сар over the windmill - nереходити межі допустимого, reinvent the wheel - відкрити Америку, be the fifth wheel - n'яте колесо до брички; інструменти та матеріали: have the dead-wood on smb - мати на когось компромат, knock on wood - постукати по дереву, shovel in monеy-загрібати гроші лопатою, put to bed with a shovel - вбитu когось. There was no need to reinvent the wheel; rather, the Committee's work should draw on accumulated experiences and collective wisdom [5]. - Немає ніякої необхідності знову відкривати Америку; швидше, роботу Комітету слід будувати на основі накопиченого досвіду й колективної мудрості. Charles said, "I haven't been sick all winter". Grandfather said, "You'd better knock on wood when you say that" [4]. - Чарльз сказав: «Я не хворів всю зиму». Дід сказав: «Краще стукай по дереву, коли ти це говориш».

Наступним є семантичний рівень - значення, яке сформувалось у результаті поєднання десемантизованих слів [2, с. 184]. На цьому рівні можна виділити такі типи: вид i застосування матерії: skeleton kеy - універсальний ключ; поведінка і стан: to bite the bullet-зчепити зуби. 21. In the end, Tom had to bite the bullet and take responsibility for his actions [4]. - У результаті Тому довелося зціпити зуби і понести відповідальність за свої дії.

Отже, під фразеологізмом із компонентом-технонімом розуміємо такий сталий зворот, де означуване містить результат або засіб інженерно-виробничого спрямування, зазнаючи впливу неживої природи. Він характеризується натурогенністю та антропогенністю, має конструктивний або деструктивний вплив на об'єкт. Типологію їх плану вираження становлять різні групи десемантизованих слів, які залежно від ступеня відношення до механічного процесу утворюють ядро і периферію вихідного поняття. 3 погляду плану змісту також спостерігаються можливі критеріï, що систематизують фразеологізми 3 компонентом-технонімом.

\section{ЛІТЕРАТУРА}

1. Крейдлин Г.Е., Кронгауз М.А. Семиотика или Азбука общения. Москва : Наука, Флинта, 2015. $326 \mathrm{c}$. 
2. Никонов Д.О. Причины обоснованности существования устойчивых оборотов с компонентом-технонимом во фразеологической системе языка. Наука и образование : сбор. статей XV междунар. науч.-практ. конф. Ч. 1. Пенза : МЦНС «Наука и Просвещение». 2018. C. $181-185$.

3. Суперанская А.В. Общая теория имени Москва : Книжный дом «ЛИБРОКОМ», 2009. 367 с.

4. Carla N. Daughtry Greenness in the Field. Michigan Today, University of Michigan. 1997. 346 p.

5. The American Heritage Dictionary of Idioms / ed. Christine Ammer. NY. : The Christine Ammer Copyright, 2010. 688 p.

6. The Phrase Finder. URL : http://www.phrases. org.uk/ (дата звернення: 19.03.2020).

\section{REFERENCES}

1. Kreydlin G.Ye., Krongauz M.A. (2015) Semiotics or the ABC of communication [Semiotika ili Azbuka obshcheniya]. M. : Science, Flinta, 326 p.
2. Nikonov D.O. (2018) Reasons for the validity of the existence of stable constructions with a component-technonym in the phraseological system of language [Prichiny obosnovannosti sushchestvovaniya ustoychivykh oborotov s komponentom-tekhnonimom vo frazeologicheskoy sisteme yazyka]. Science and Education: Collection of articles of the XV International Scientific and Practical Conference, Part 1, Penza : ICNS "Science and Education", P. 181-185.

3. Superanskaya A. V. (2009) General theory of the name [Obshchaya teoriya imeni]. M. : Book House "LIBROKOM", 367 p.

4. Carla N. (1997) Daughtry Greenness in the Field. Michigan Today, University of Michigan, $346 \mathrm{p}$.

5. The American Heritage Dictionary of Idioms (ed. Christine Ammer). (2010). NY. : The Christine Ammer Copyright, $688 \mathrm{p}$.

6. The Phrase Finder. URL: http://www.phrases.org.uk/ 